\title{
PERANCANGAN REAKTOR KOMPOS
}

\author{
COMPOST REACTOR DESIGN
}

\author{
Anggi Wahyuningsi ${ }^{1)}$, Sulton Amna ${ }^{2)}$ \\ ${ }^{1,2)}$ Program Studi Teknik Pengolahan Migas Politeknik Akamigas Palembang, 30257, Indonesia \\ Corresponding Author E-mail:anggi_w@pap.ac.id dan sulton@pap.ac.id
}

\begin{abstract}
Utilization of organic waste into compost is one of the right alternatives to tackle organic waste without damaging the environment. This research, compost is made in a compost reactor. The results showed the success of the compost reactor as a means of making compost in 14 days. The first day of compost is still in the form of the initial compost dough, the eighth day the remaining vegetables are wilted slightly brownish, there are still green vegetables, the aroma is still weak and the fourteenth day the rest of the vegetables are completely withered, darker brown than before and have merged (resembling soil), the aroma is a bit pungent. smell of tapai, it has become compost ready for use.
\end{abstract}

Keywords: organic waste, inorganic waste, compost, environment, anaerobic

Abstrak: Pemanfaatan limbah organik menjadi kompos merupakan salah satu alternatif yang tepat untuk menanggulangi limbah organik tanpa merusak lingkungan Dalam penelitian ini, kompos dibuat di dalam reaktor kompos. Hasil penelitian menunjukkan keberhasilan reaktor kompos sebagai sarana pembuatan kompos dalam waktu 14 hari. Kompos hari pertama masih berupa adonan awal kompos, hari kedelapan sisa sayuran layu agak kecoklatan masih terdapat sayuran yang berwarna hijau aromanya masih lemah dan hari keempatbelas sisa sayuran melayu keseluruhan, berwarna coklat lebih gelap dari semula dan sudah menyatu (menyerupai tanah) aroma sedikit menusuk semacam bau tapai, sudah menjadi pupuk kompos yang siap dipakai.

Kata kunci : sampah organik, sampah anorganik, kompos, lingkungan, anaerob

\section{PENDAHULUAN}

Dalam ilmu geologi, tujuan mempelajari fosil energi tak terbarukan adalah untuk mempelajari perkembangan kehidupan yang pernah ada di muka bumi sepanjang sejarah bumi, mengetahui kondisi geografi dan iklim pada zaman saat fosil tersebut hidup, menentukan umur relatif batuan yang terdapat di alam didasarkan atas kandungan fosilnya.

Maka dari itu, seiring berkembangnya teknologi ketika pemanfaatan energi-energi tak terbarukan semakin menipis maka biomassa mulai diperhitungkan menjadi solusi alternatif, terlebih lagi saat kelompok hijau makin keras menyuarakan penghematan energi, Biomassa kemudian menjadi salah satu pilihan karena relatif dikelola dan dapat diperbaharui sehingga dapat menyediakan sumber energi secara berkesinambungan.

Biomassa yang sebenarnya sudah dikenal sejak zaman dulu. Selain digunakan untuk bahan pangan, pakan ternak, minyak nabati, bahan bangunan dan sebagainya, biomassa juga digunakan sebagai sumber energi (bahan bakar). Biomassa yang umum yang digunakan sebagai bahan bakar adalah yang memiliki nilai ekonomis rendah atau merupakan limbah setelah diambil produk primernya.

Selain pemanfaatan limbah biomassa sebagai pakan ternak juga akan menghasilkan limbah peternakan sama hal nya dengan limbah-limbah sisa bahan pangan yang menumpuk di pasaran. Hal ini dapat ditanggulangi dengan cara pemanfaatan lebih lanjut limbah-limbah tersebut yang dapat berupa sisa-sisa sayuran, buah-buahan dan lain sebagainya sebagai bahan utama yang mampu bersinergi untuk mengentaskan krisis pupuk kompos organik yang dikarenakan penggunaan pupuk buatan pabrik yang semakin tinggi takarannya dapat menyebabkan tanah menjadi rusak sehingga produktivitas pangan menurun dan ketahanan pangan pun melemah. Bertolak dari permasalahan diatas, penelitian ini mencoba merealisasikan upaya yang harus 
dilakukan yaitu dengan melakukan praktik dalam pemanfaatan limbah organik. Berdasarkan uraian di atas, proses pengomposan bisa terjadi dengan sendirinya pada alam terbuka. Lewat proses alami, rumput, daun-daunan dan kotoran hewan serta sampah lainnya lama kelamaan membusuk karena adanya kerja sama antara mikroorganisme dengan cuaca. Proses tersebut bisa dipercepat oleh perlakuan manusia, yaitu dengan menambahkan mikroorganisme pengurai dan media yang kita sebut reaktor kompos sehingga dalam waktu singkat akan diperoleh kompos yang berkualitas baik.

\section{TEORI DASAR}

\subsection{Pengertian Biomassa}

Biomassa merupakan salah satu sumber energi terbarukan sehingga energi ini dapat diperoleh dari sumber-sumber yang dapat diproduksi lagi, salah satunya yaitu tumbuhan yang ada di alam, bahan organik yang hidup maupun yang mati, baik di atas permukaan tanah maupun yang ada di bawah permukaan tanah atau dengan kata lain adalah bahan organik yang dihasilkan melalui proses pembusukan, baik berupa produk maupun buangan. Keunggulan lain dari biomassa adalah harganya yang lebih murah dibandingkan dengan sumber energi lainnya. Kondisi ini dapat terjadi karena jumlahnya yang sangat melimpah dan umumnya merupakan limbah dari suatu aktifitas masyarakat sendiri.

\subsection{Limbah Masyarakat (Rumah Tangga dan Pasar)}

Limbah masyarakat yang dimaksud ini adalah limbah yang berasal dari rumah tangga dan pasar yang berupa limbah organiknya yaitu sisa-sisa sayuran yang terbuang ataupun sudah busuk dan juga sisa-sisa kulit buahbuahan yang dapat dikelola kembali menjadi pupuk kompos organik. Muktiani dkk. (2005) menyatakan bahwa limbah sayuran di pasar memiliki kandungan Protein Kasar (PK) 23,87 $\%$, Serat Kasar (SK) 22,62 \%, Lemak Kasar (LK) $1,75 \%$, Abu 12,50 \%. Limbah sisa-sisa sayuran juga berpotensi sebagai pengawet maupun sebagai starter fermentasi karena memiliki kandungan asam tinggi dan mikrobia yang menguntungkan. Asam pada limbah pasar sayur diduga berupa asam laktat sebagai hasil metabolisme bakteri asam laktat.

\subsection{Konversi dan Pemanfaatan Energi Biomassa \\ Penggunaan biomassa untuk} menghasilkan panas secara sederhana yaitu biomassa langsung dibakar dan menghasilkan panas. Dan panas hasil pembakaran akan dikonversi menjadi energi listrik melali turbin dan generator. Panas hasil pembakaran biomassa akan menghasilkan uap dalam boiler. Uap akan ditransfer kedalam turbin sehingga akan menghasilkan putaran dan menggerakan generator. Putaran dari turbin dikonversi menjadi energi listrik melalui magnet-magnet dalam generator.

Teknologi konversi biomassa menjadi bahan bakar dapat dibedakan menjadi tiga yaitu pembakaran langsung, konversi termokimiawi dan konversi biokimiawi. Pembakaran langsung merupakan teknologi yang paling sederhana karena pada umumnya biomassa telah dapat langsung dibakar. Beberapa biomassa perlu dikeringkan terlebih dahulu dan didensifikasi untuk kepraktisan dalam penggunaan. Konversi termokimiawi merupakan teknologi yang memerlukan perlakuan termal untuk memicu terjadinya reaksi kimia dalam menghasilkan bahan bakar. Sedangkan konversi biokimiawi merupakan teknologi konversi yang menggunakan bantuan mikroba dalam menghasilkan bahan bakar.

\subsection{Gasifikasi}

Gasifikasi biomassa dapat didefinisikan sebagai proses konversi bahan selulosa dalam suatu reaktor gasifikasi (gasifier) menjadi bahan bakar. Gas tersebut dipergunakan sebagai bahan bakar motor untuk menggerakan generator pembangkit listrik. Gasifikasi merupakan salah satu alternatif dalam rangka program penghematan dan diversifikasi energi. Selain itu gasifikasi akan membantu mengatasi masalah penanganan dan pemanfaatan limbah pertanian, perkebunan, dan kehutanan. 


\subsection{Biokimia}

Pemanfaatan energi biomassa yang lain adalah dengan cara proses biokimia. Contoh proses yang termasuk ke dalam proses biokimia adalah hidrolisis, fermentasi, dan anaerobic digestion. Anaerobic digestion adalah penguraian bahan organik atau selulosa menjadi $\mathrm{CH}_{4}$ dan gas lain melalui proses biokimia.

Biomassa yang kaya dengan karbohidrat atau glukosa dapat difermentasi sehingga terurai menjadi etanol dan $\mathrm{CO}_{2}$. Akan tetapi, karbohidrat harus mengalami penguraian (hidrolisis) terlebih dahulu menjadi glukosa. Etanol hasil fermentasi pada umumnya mempunyai kadar air yang tinggi dan tidak sesuai untuk pemanfaatannya sebagai bahan bakar pengganti bensin. Etanol ini harus didistilasi sedemikian rupa mencapai kadar etanol di atas $99.5 \%$.

\subsection{Reaktor}

Reaktor adalah suatu alat proses tempat dimana terjadinya suatu reaksi berlangsung,baik itu reaksi kimia atau reaksi nuklir dan bukan secara fisika. Reaktor kimia adalah segalatempat terjadinya reaksi kimia, baik dalam ukuran kecil seperti tabung reaksi sampai ukuranyang besar seperti reaktor skala industri.

Reaktor adalah jantung dari proses kimia. Reaktor adalah suatu tempat proses dimanabahan-bahan diubah menjadi produk, dan perancangan reaktor untuk industri kimia harus mengikuti keperluan: Faktor kimia, faktor transfer panas, faktor transfer massa, faktor keselamatan (Coulson, 1983).

Perubahan energi dalam suatu reaktor kimia bisa karena adanya suatu pemanasan atau pendinginan, penambahan atau pengurangan tekanan, gaya gesekan (pengaduk dan cairan). Berikut ini merupakan macammacam reaktor:

\section{Reaktor Batch}

Reaktor Batch merupakan jenis reaktor yang digunakan untuk meningkatkan selektivitas reaksi fase cair.

2. Reaktor Kontinyu
Reaktor kontinyu merupakan reaktor yang beroperasi secara terus-menerus dimana reaktan akan terus mengalir dan diikuti reaksi disepanjang reaktor.

3. Bioreaktor

Reaktor tempat terjadinya proses biologis secara anaerob seperti pengomposan dan fermentasi.

\section{METODOLOGI PENELITIAN 3.1 Alat dan Bahan Penelitian}

Alat dalam penelitian, yaitu: drum, pipa PVC, valve, ban dalam, selang gas, saringan dan kasa. Bahan dalam penelitian yaitu limbah sayur, bioaktivator (EM4), dan gula.

\subsection{Desain Rancangan Reaktor}

Desain reaktor seperti terlihat pada gambar berikut:

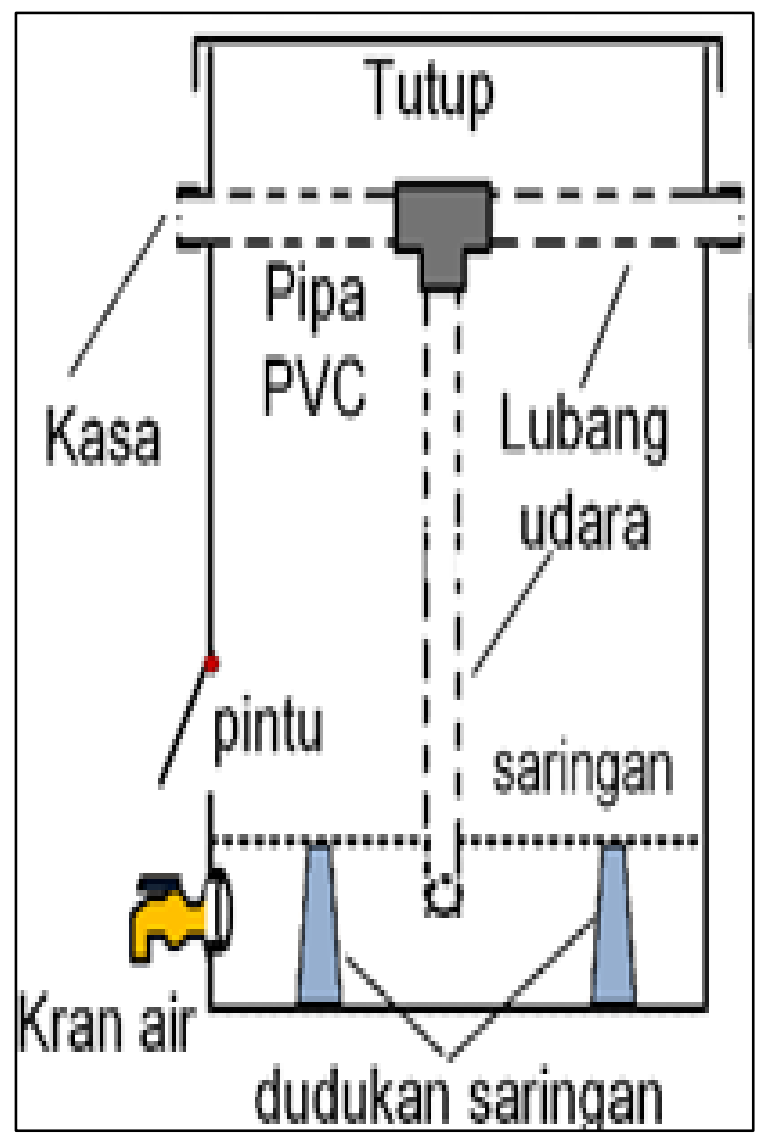

Sumber: www.daunijo.com

Gambar 3.1 Desain Rancangan Reaktor 


\subsection{Pembuatan Kompos}

Berikut diberikan bagan pembuatan kompos:

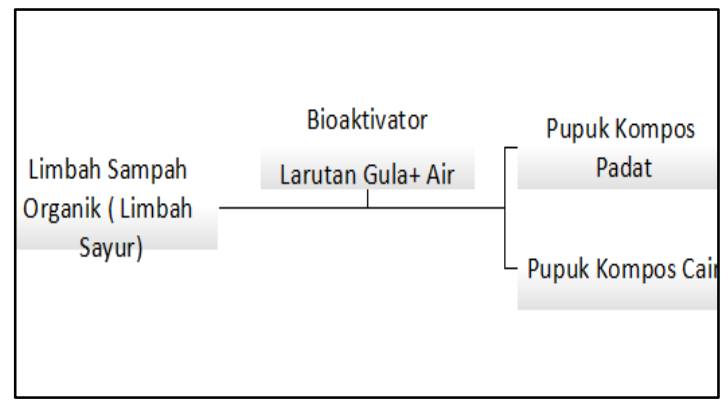

Gambar 3.2 Desain Rancangan Reaktor

4. HASIL DAN PEMBAHASAN

\subsection{Hasil Pembuatan Kompos Menggunakan Reaktor Kompos}

Tabel 4.1 Hasil Pengamatan Dari Pembuatan Pupuk Kompos Menggunakan Reaktor

Kompos

\begin{tabular}{|l|l|}
\hline Hari & \multicolumn{1}{|c|}{ Hasil Pengamatan } \\
\hline Hari ke-1 & Masih berupa adonan awal kompos \\
\hline Hari ke-5 & $\begin{array}{l}\text { Sisa sayuran tidak nampak berubah } \\
\text { drastis seperti semula, aroma tidak } \\
\text { terlalu bau. }\end{array}$ \\
\hline Hari ke-8 & $\begin{array}{l}\text { Sisa sayuran layu agak kecoklatan } \\
\text { masih terdapat sayuran yang } \\
\text { berwarna hijau aromanya masih } \\
\text { lemah. ke-14 }\end{array}$ \\
$\begin{array}{l}\text { Sisa sayuran melayu keseluruhan, } \\
\text { berwarna coklat lebih gelap dari } \\
\text { semula dan sudah menyatu } \\
\text { (menyerupai tanah) aroma sedikit } \\
\text { menusuk semacam bau tapai. Sudah } \\
\text { menjadi pupuk kompos yang siap } \\
\text { dipakai }\end{array}$ \\
\hline
\end{tabular}

\subsection{Pertumbuhan dan Hasil Tanaman Cabai}

Indikator pertumbuhan suatu tanaman adalah adanya peningkatan volume dan berat. Peningkatan volume dan berat organ dapat dilihat antara lain dari adanya penambahan tinggi tanaman, diameter batang, dan umur berbunga, sedangkan jumlah buah per tanaman, berat buah, dan hasil buah segar menujukkan adanya pertumbuhan melalui peningkatan hasil.
4.2.1. Tanaman
Cabai Menggunakan Pupuk Kompos

Tabel 4.2 Tanaman Cabai Tidak Menggunakan Pupuk Kompos

\begin{tabular}{|c|c|c|}
\hline Hari ke- & $\begin{array}{c}\text { Tinggi } \\
\text { tanaman }\end{array}$ & $\begin{array}{c}\text { Pertumbuhan } \\
\text { panjang/hari }\end{array}$ \\
\hline 1 & $7 \mathrm{~cm}$ & - \\
\hline 2 & $7 \mathrm{~cm}$ & - \\
\hline 3 & $7 \mathrm{~cm}$ & - \\
\hline 4 & $7,1 \mathrm{~cm}$ & $0,1 \mathrm{~cm}$ \\
\hline 5 & $7,1 \mathrm{~cm}$ & - \\
\hline 6 & $7,2 \mathrm{~cm}$ & $0,1 \mathrm{~cm}$ \\
\hline 7 & $7,2 \mathrm{~cm}$ & - \\
\hline
\end{tabular}

$$
\begin{aligned}
\text { Epertumbuhan } & =\frac{(0,1+0,1) \mathrm{cm}}{6 \text { hari }}=\frac{0,2 \mathrm{~cm}}{6 \text { hari }} \\
& =0,034 \mathrm{~cm} / \text { hari }
\end{aligned}
$$

Hasil pertumbuhan didapatkan 0,034 $\mathrm{cm} /$ hari dan tanah menjadi padat

\subsubsection{Tanaman Cabai Dengan Penambahan Pupuk Kompos}

Tabel 4.2 Tanaman Cabai Dengan Penambahan Pupuk Kompos

\begin{tabular}{|c|c|c|}
\hline Hari ke- & $\begin{array}{c}\text { Tinggi } \\
\text { tanaman }\end{array}$ & $\begin{array}{c}\text { Pertumbuhan } \\
\text { panjang/hari }\end{array}$ \\
\hline 1 & $6,5 \mathrm{~cm}$ & - \\
\hline 2 & $6,9 \mathrm{~cm}$ & $0,4 \mathrm{~cm}$ \\
\hline 3 & $7,5 \mathrm{~cm}$ & $0,6 \mathrm{~cm}$ \\
\hline 4 & $8,0 \mathrm{~cm}$ & $0,5 \mathrm{~cm}$ \\
\hline 5 & $8,7 \mathrm{~cm}$ & $0,7 \mathrm{~cm}$ \\
\hline 6 & $9,3 \mathrm{~cm}$ & $0,6 \mathrm{~cm}$ \\
\hline 7 & $9,8 \mathrm{~cm}$ & $0,5 \mathrm{c}, \mathrm{m}$ \\
\hline
\end{tabular}

Rata-rata pertumbuhan $=\frac{(0,4+0,6+0,5+0,7+0,6+0,5) \mathrm{cm}}{6 \mathrm{hari}}$

$$
=0,55 \frac{\mathrm{cm}}{\text { hari }}
$$

Hasil pertumbuhan didapatkan 0,55 $\mathrm{cm} /$ hari dan tanah lebih gembur.

\section{KESIMPULAN DAN SARAN}

\subsection{Kesimpulan}

Reaktor kompos yang dibuat dengan desain sederhana dapat digunakan dengan baik.

\section{DAFTAR PUSTAKA}

Fitriani, Y. 2008. Pembuatan Pupuk Organik Cair dari Limbah Sayur dan Buah Menggunakan Tambahan Larutan EM4 
(Effective Microorganisme 4). Skripsi. Bogor: Institut Pertanian Bogor.

Jalaludin, dkk.. 2016. Pengolahan sampah organik buah-buahan menjadi pupuk dengan menggunakan Effective mikroorganisme. Jurnal Teknologi Kimia Unimal. 5(1), hlm. 1720.

Leovini, H. 2012. Pemanfaatan Pupuk Organik Cair Pada Budidaya

Tanaman Cabai. Jurusan Budidaya Pertanian, Fakultas Pertanian Universitas Gadjah Mada.

Marliani, Novi. 2014. Pemanfaatan Limbah Rumah Tangga (Sampah Anorganik) Sebagai Bentuk Implementasi Dari Pendidikan Lingkungan. 
P-ISSN: 2089-5925 E-ISSN: 2621-9328

A

Jurnal Teknik Patra Akademika

PATRA

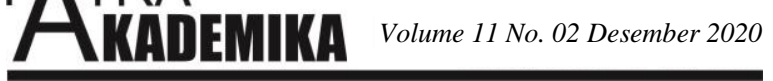

